\title{
'Eylul': A New Late Ripening Apricot Cultivar for Fresh Market
}

\author{
Bayram Murat Asma1 \\ Faculty of Agriculture, Department of Horticulture, Inonu University, \\ Battalgazi, Malatya 44210, Turkey
}

Zehra Tuğba Murathan

Faculty of Engineering, Department of Food Engineering, Ardahan University, Ardahan 7500, Turkey

Tuncay Kan and Firat Ege Karaat

Faculty of Agriculture, Department of Horticulture, Inonu University, Battalgazi, Malatya 44210, Turkey

\section{Ogün Birhanlı}

Faculty of Education, Department of Life Sciences, Inonu University, Malatya 44280, Turkey

\section{Abdullah Erdoğan \\ Apricot Researh Institue, Aşă̆ $ı$ băglar Mah. Ismetpaşa Cad. No: 163, Yeşilyurt, Malatya 44250, Turkey}

Additional index words. Prunus armeniaca, fruit breeding, late ripening, fruit quality

'Eylul' is the most recent apricot (Prunus armeniaca L.) cultivar bred in the MultiPurpose Apricot Breeding Program of Inonu University, Malatya, Turkey, and released for propagation in 2017. 'Eylul' means September in Turkish which addresses its late ripening characteristics. The cultivar is selfcompatible and capable of setting full crops without the presence of other cultivars. Besides, it successfully adapts Malatya, the main apricot production area in the world. 'Eylul' fruit ripen late, with a fruit development period of $149 \mathrm{~d}$, and are suitable for fresh consumption with good fruit quality and productivity. Fruit are oblong shaped and are pleasant dull gold-yellow in skin color with red blush covering $5 \%$ to $10 \%$ of the fruit skin. From adequately thinned trees, growers can expect $30-35 \mathrm{~g}$ fruit that are juicy and having more than $17 \%$ soluble solid content and moderate acidity.

\section{Origin}

'Eylul' resulted from a cross between Turkish apricots of unknown origin: 'Aprikoz' (synonymous 'Shalakh') and 'Levent' cultivars. 'Aprikoz' is a table cultivar selected in Iğdır-Kağızman region, located in the eastern part of Turkey. Fruit of 'Aprikoz' are $50-65 \mathrm{~g}$ in weight, oblong shaped, with

Received for publication 2 Mar. 2018. Accepted for publication 19 Apr. 2018.

This research was supported by grants TOGTAG-3099 and TOVAG 1060665 from the Scientific and Technological Research Council of Turkey (TUBITAK).

${ }^{1}$ Corresponding author. E-mail: bayram.asma@ inonu.edu.tr. yellow-colored fruit skin and flesh, sweet, moderately firm textured, having $17 \%$ to $20 \%$ total soluble solids and $0.3 \%$ to $0.5 \%$ acidity. Harvest date of 'Aprikoz' is late July in Malatya. 'Levent' was selected by an apricot grower from Levent, a small town of Malatya Province, as chance seedling in 1993. Fruit of 'Levent' are 20-25 g in weight and ripen in 180-200 d after full bloom, which is an extremely late-ripening cultivar (Asma, 2007; Ledbetter, 2008). The primary evaluation of the seedling from which 'Eylul' was selected was made in 2007 , and nine selections were set aside as the most promising for further observation. These genotypes were grafted on apricot seedlings and planted in the research plot at $5 \times 5-\mathrm{m}$ intervals with five replications. Reference cultivars Aprikoz, Levent, and Dilbay were also included for comparison purposes. Dilbay was the first apricot cultivar released from the MultiPurpose Apricot Breeding Program of Inonu University, Malatya, Turkey (Asma, 2012). All apricot saplings were cultivated under similar horticulture management practices in the same orchard. Data were collected for four consecutive years from 2012 to 2016 . Data from 2014 were not included because of late frosts that prevented fruit set. Among the nine selections included in the experiment, 'Eylul' ('Apr' $\times$ 'Lev' 34) was selected for release because of its combined performance in terms of adaptation to environmental conditions, fruit quality, yield, and late ripening.

\section{Description}

Tree characteristics. The growth habit of 'Eylul' is upright to spreading (such as 'Early Orange' and 'Palsteyn' cultivars) and vigorous (such as 'Tyrinthos' and 'Veecot' cultivars) according to UPOV (2007) (Table 2). The growing shoot tip presents anthocyanin coloration in springtime. One-year-old shoots are red-brown. The leaves are medium in size, dark green in color, and narrow in shape. Leaf base is truncate in shape and the angle of the tip is acute. Leaf margins are medium serrated. Petioles have an average three to five small glands.

Plum pox virus resistance. Plum pox virus (PPV) is the causal agent of Sharka disease, which is mainly destructive on apricot, cherry, plum, and peach. The nine selections under trial from the Multi-Purpose Apricot Breeding Program were screened for resistance to PPV with PGS1.21 and PGS2.23 molecular markers designed by Soriano et al. (2012). Unfortunately, PPV resistance alleles were not detected for 'Eylul', 'Levent', 'Aprikoz', and 'Dilbay'.

Flowering characteristics. The flower buds of 'Eylul' are formed on both 1- and 2 -year-old shoots with a very high flowering density. Flowers are of a diameter typical of commercial apricot and stigmas are typically level with the anthers. Petals are oblate in shape and white. 'Eylul' is distinguished as the earliest blossoming cultivar among local cultivars. In 2012, winter was colder and longer than average in Malatya. For that reason, bloom of all cultivars was delayed for 15-20 d, and it was 5 Apr. when bloom began for 'Eylul'. On the other hand, full bloom date was 10 Mar. in 2016 (Table 1). Long-term average for full bloom date across major apricot cultivars in Malatya is 20-30 Mar. (Asma, 2011). The chilling requirement of 'Eylul' has been calculated at $914 \pm 45 \mathrm{~h}$ based on the standard method (hours below $\left.7.2^{\circ} \mathrm{C}\right)$ described by Byrne and Bacon $(1992)$ in Malatya (lat. $38^{\circ} 28^{\prime} 58^{\prime \prime} \mathrm{N}$, long. $38^{\circ} 21^{\prime} 08$ "E, $730 \mathrm{~m})$. The number of anthers and pollen grains per anther in 'Eylul' flowers are 29 and $2.200-2.850$, respectively. According to triphenyltetrazolium chloride test, pollen viability is $69 \%$ to $75 \%$. Pollen germination rate is $65 \%$ to $71 \%$ under in vitro tests performed on media having $1 \%$ agar and $15 \%$ sucrose at $20^{\circ} \mathrm{C}$. 'Eylul' flowers are self-compatible and produce high amount of

Table 1. Four years of bloom and harvest ranges in Battalgazi region, Malatya, for new late-ripening apricot 'Eylul' and its parents ('Aprikoz' and 'Levent') and reference cultivar Dilbay.

\begin{tabular}{|c|c|c|c|c|c|c|c|c|}
\hline \multirow[b]{2}{*}{ Crop yr } & \multicolumn{2}{|c|}{ Eylul } & \multicolumn{2}{|c|}{ Aprikoz } & \multicolumn{2}{|c|}{ Levent } & \multicolumn{2}{|c|}{ Dilbay } \\
\hline & Full bloom & Harvest & Full bloom & Harvest & Full bloom & Harvest & Full bloom & Harvest \\
\hline 2012 & & & & & & & & \\
\hline 13 & 5 Mar. & $23 \mathrm{Al}$ & 18 Mar. & 17. & 15 Mar. & & 20 Mar. & 8 June \\
\hline 015 & 24 Mar. & 11 Aug. & 28 Mar. & 26 June & 25 Mar. & 5 Sept. & 29 Mar. & 18 June \\
\hline 016 & 10 Mar. & 13 Aug. & 12 Mar. & 14 June & 10 Mar. & 7 Sept. & 13 Mar. & 4 June \\
\hline
\end{tabular}


pollen by the methods proposed by Burgos et al. (1993).

Fruit characteristics. The fruit of 'Eylul' are oblong in shape. The pit can easily be removed from the fruit, which is a benefit for the consumers. Kernels are sweet. The fruit skin is smooth and has a pleasant dull goldyellow skin color (Fig. 1). Skin cracking and pit burning were not observed in any of the cultivars tested during the experimental period. Flesh color is cream and flesh texture is finely grained and firm. The fruit are juicy, with total soluble solid content averaging $17.9 \%$ and titratable acidity being $0.58 \%$. These values result in a Brix/acid ratio of 30.9 for 'Eylul', whereas the ratio is just

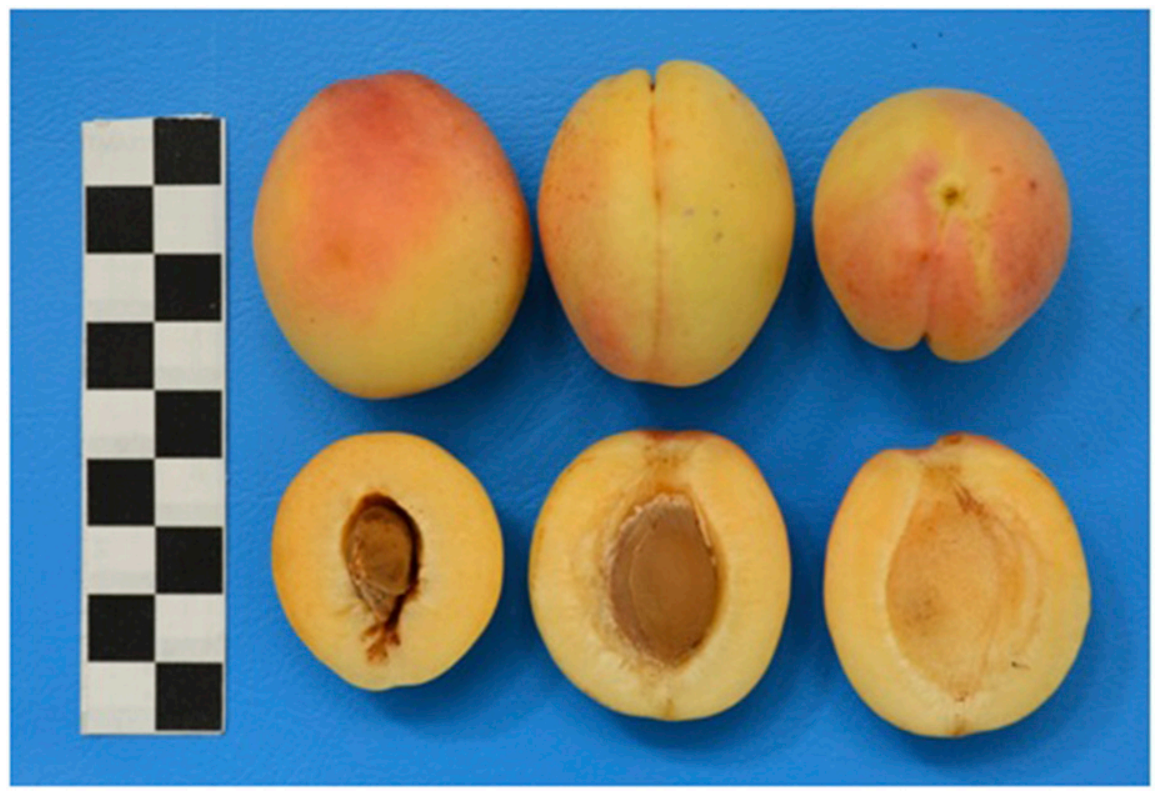

Fig. 1. Fruit of 'Eylul' apricot (each square edge represents $10 \mathrm{~mm}$ in length).

Table 2. Comparative results of tree and fruit characteristics of 'Eylul', its parents 'Aprikoz' and 'Levent', and the new early-ripening Turkish cultivar Dilbay.

\begin{tabular}{|c|c|c|c|c|}
\hline Characteristics & Eylul & Aprikoz & Levent & Dilbay \\
\hline \multicolumn{5}{|l|}{ Tree } \\
\hline Vigor & Vigorous & Very vigorous & Vigorous & Vigorous \\
\hline Flower density & Very high & High & Medium & High \\
\hline Compatibility & Self-compatible & Self-compatible & Self-incompatible & Self-compatible \\
\hline Fruit set $(1-9)^{z}$ & 7 & 9 & 6 & 8 \\
\hline Yield $(1-9)^{\mathrm{y}}$ & 6 & 9 & 5 & 7 \\
\hline \multicolumn{5}{|l|}{ Fruit } \\
\hline $\begin{array}{l}\text { Days from full bloom } \\
\text { to maturity }\end{array}$ & $149 \pm 3.54$ & $91 \pm 1.25$ & $176 \pm 5.30$ & $81 \pm 0.82$ \\
\hline Fruit size $(\mathrm{g})$ & $32.5 \pm 1.47$ & $68.7 \pm 3.92$ & $21.4 \pm 0.88$ & $59.2 \pm 3.12$ \\
\hline Firmness $\left(\mathrm{kg} \cdot \mathrm{cm}^{-2}\right)$ & $2.7 \pm 0.25$ & $2.4 \pm 0.53$ & $2.8 \pm 0.25$ & $2.7 \pm 0.75$ \\
\hline Skin color & Yellow & Light yellow & Yellow & Light orange \\
\hline Flesh color & Cream & Light yellow & Yellow & Light orange \\
\hline Percent red blush & $10 \pm 3.55$ & - & $15 \pm 5.81$ & $30 \pm 12.45$ \\
\hline Total soluble solid (\%) & $17.9 \pm 0.96$ & $15.5 \pm 1.22$ & $20.5 \pm 2.35$ & $15.1 \pm 1.47$ \\
\hline${\text { Titratable } \text { acidity }^{\mathrm{x}}}$ & $0.58 \pm 0.07$ & $0.49 \pm 0.09$ & $0.58 \pm 0.08$ & $0.76 \pm 0.07$ \\
\hline Kernel bitterness & Sweet & Sweet & Sweet & Sweet \\
\hline PPV resistance alleles & Not detected & Not detected & Not detected & Not detected \\
\hline
\end{tabular}

$\mathrm{z}_{1}=$ the least and $9=$ the most.

${ }^{y_{1}}=$ the least and $9=$ the most

${ }^{\mathrm{x}}$ Titratable acidity expressed as grams of malic acid per $100 \mathrm{~mL}$.

$\mathrm{PPV}=$ Plum pox virus.
19.9 for reference cultivar Dilbay (Table 2). Brix/acid ratio is an important factor for consumer acceptance with higher ratios, denoting higher eating quality (Jayasena and Cameron, 2008). This ratio is 31.6 for 'Aprikoz', 35.3 for 'Levent', 19.86 for 'Dilbay', 86.6 for 'Hacihaliloğu', 7.4 for 'Ninfa', and 12.4 for 'Stark Early Orange' (Asma, 2011).

Maturation time. The maturation periods of Eylul, its parents, and reference cultivars were determined in a 4-year study (Table 1). During the observation period, the latest harvest was carried out on 2 Sept. in 2012 , and the earliest was in 2015 (11 Aug.). Harvest date varied 20-25 d between the

years. Full bloom and harvest were both earlier in warmer and arid years. The average number of days from full bloom to harvest (fruit development period) was $149 \mathrm{~d}$ for 'Eylul', 91 d for 'Aprikoz', 176 d for 'Levent', and $81 \mathrm{~d}$ for reference cultivar Dilbay.

Fruit size, color, and flesh firmness. The average fruit weights of 'Eylul' and its parents 'Levent' and 'Aprikoz' are 32.5, 21.4 , and $68.7 \mathrm{~g}$, respectively. Flesh firmness is $2.7 \mathrm{~kg} \cdot \mathrm{cm}^{-2}$ in 'Eylul', $2.4 \mathrm{~kg} \cdot \mathrm{cm}^{-2}$ in 'Aprikoz', and $2.8 \mathrm{~kg} \cdot \mathrm{cm}^{-2}$ in 'Levent' (Table 2). The skin color of 'Eylul' is yellow, with a red blush encompassing only $5 \%$ to $10 \%$ of the fruit surface area. Red blush was not observed on 'Aprikoz', whereas 'Levent' typically exhibits only $15 \%$. However, on the fruit of the reference cultivar Dilbay, more than $30 \%$ of the fruit surface is covered in red blush. Skin ground color of 'Eylul', as measured with a Minolta CR-300 Chroma Meter, was observed in " $L$," " $a$," and " $b$ " values averaging $73.61,10.26$, and 41.87 , respectively, with associated hue angle being $76.23^{\circ}$, whereas these same average values for flesh color were $86.40,5.74$, and 36.61 , respectively, with an associated hue angle of $81.09^{\circ}$.

\section{Availability}

'Eylul' is available for propagation and the cultivar has been registered by the Cultivar Registration and Seed Certification Center of Turkish Ministry of Food, Agriculture and Livestock on 3 Nov. 2017. The mother tree of 'Eylul' is located on the Battalgazi Campus of Inonu University in Malatya, Turkey. Limited quantities of budwood are usually available on request for all trial or research purposes, including the breeding of new cultivars.

\section{Literature Cited}

Asma, B.M. 2007. Malatya: The world's capital of apricot culture. Chronica Hort. 47:20-24.

Asma, B.M. 2011. Apricot with all aspects (in Turkish). Uyum Ajans, Ankara, Turkey.

Asma, B.M. 2012. A new early-ripening apricot, 'Dilbay'. HortScience 47:1367-1368.

Burgos, L., T. Berenguer, and J. Egea. 1993. Selfand cross-compatibility among apricot cultivars. HortScience 28:148-150.

Byrne, D.H. and T.A. Bacon. 1992. Chilling estimation: Its importance and estimation. The Texas Hort. 18:8-9.

Jayasena, V. and I. Cameron. 2008. Brix/acid ratio as a predictor of consumer acceptability of crimson seedless table grapes. J. Food Qual. 31:736-750.

Ledbetter, C.A. 2008. Apricots, p. 39-82. In: J.F. Hancock (ed.). Temperate fruit crop breeding. Springer, Berlin, Heidelberg, New York.

Soriano, J.M., M.L. Domingo, E. Zuriaga, C. Romero, T. Zhebentyayeva, A.G. Abbott, and M.L. Badenes. 2012. Identification of simple sequence repeat markers tightly linked to Plum pox virus resistance in apricot. Mol. Breeding 30(2):1017-1026.

UPOV. 2007. Apricot descriptor, International Union for the Protection of New Varieties of Plants (UPOV). 7 Apr. 2018. <http://www.upov. int/edocs/tgdocs/en/tg070.pdf>. 